\title{
HISTORICAL LAWS OF BALTIC ACCENTUATION
}

\section{Introduction}

Since the publication of my monograph on Slavic accentuation (1975), substantial progress has been made in the study of the subject. The main problem which remained in the theory advanced there, the origin of the acute intonation in such words as Lith. bëgti, ësti, sësti (1975:22ff.), was solved by W. Winter in his contribution to the Ustronie conference on historical phonology (1976). It was shown in his paper that a Proto-Indo-European sequence of short vowel plus voiced stop is reflected by an acute long vowel plus voiced stop in Baltic and Slavic, whereas a short vowel plus voiced aspirate yields a short vowel plus voiced stop. As I pointed out in my comment on the paper, this first-rate discovery has far-reaching consequences for the reconstruction of the Indo-European proto-language. It provides the unexpected key-stone for Gamkrelidze and Ivanov's theory that the voiced stops of the proto-language were actually glottalic (1973). This theory, which suggested itself on typological grounds, is now supported by immediate comparative evidence. One arrives at the conclusion that the Balto-Slavic acute intonation continues the Proto-Indo-European laryngeals and the glottalic feature of the "voiced" consonants, while the Balto-Slavic circumflex reflects the early contractions and the lengthened grade. Thus, the glottal articulation in Latv. pẹds, nuogss represents the same kind of a posteriori evidence for the theory of glottalic consonants as the initial velar of Hitt. hanti, hastai once provided for laryngeal theory.

Here again I have to stress that the Indo-European lengthened grade is never reflected by an old acute in Balto-Slavic, in spite of the current view on this matter (e. g.. Watkins 1965). As F. de Saussure pointed out more than eighty years ago, "à part deux ou trois cas spéciaux (allongement du nominatif, allongement de l'aoriste sigmatique, etc.), l'alternance $e-\bar{e}$ n'est pas indo-européenne" (1922:493), and in these few cases we find a circumflex in Balto-Slavic. The original distribution has been obscured by various types of metatony and analogy.

Gamkrelidze and Ivanov reinterpret the two series of Indo-European stops so far taken to be voiced and voiceless as glottalized and voiceless aspirate, respectively. "Das Merkmal Aspiration gilt in einem derartigen System als redundante Eigenschaft der entsprechenden Phoneme. Vom streng phonologischen Standpunkt aus könnte man die drei genannten Serien als glottalisiert/stimmhaft/stimmlos kennzeichnen" (1973: 155). I would go even one step further and claim that voicedness was not a distinctive feature in the Indo-European proto-language. Thus, I would reconstruct $t^{\prime} t^{c} t$ : for Gamkrelidze and Ivanov's $t^{\prime} d h$ th and traditional $d d h t$. This hypothesis, which, among other things, accounts for the apparent merger of the three series in Hittite, leads to a large number of 
simplifications in historical phonology, e. g. in the derivation of Sanskrit sandhi rules. Since a full discussion of the matter falls outside the scope of this paper, I shall confine myself to a single remark here. Classical methods of reconstruction point to a single Proto-Indo-European word-final stop, viz. ${ }^{*} d$, cf. Latin quod, Old High German $h w a z$. The typological improbability of this reconstruction is eliminated if one assumes that the laryngeal feature which differentiated * $d$ from $* t$ was not voicedness.

As to the chronology of Winter's law, which I now reformulate as the transfer of the laryngeal feature from a glottalic consonant to a preceding vowel, I think that it must be dated to the very end of the Balto-Slavic period. The merger of the feature with the reflex of the Proto-Indo-European laryngeals was certainly posterior to Hirt's law (cf. Kortlandt $1975: 2$ ) because the stress was not retracted in the forms which were to develop into Latv. pêds, nuôgs. The non-final stress in Russ. séla is probably old in view of the rising pitch in the 3rd sg. aor. SCr. lèze, which points to final stress as a result of the progressive accent shift known as Dybo's law (cf. Kortlandt $1975: 14$ ). This view is corroborated by the absence of sigmatic aorist forms of these verbs in Old Church Slavic (cf. Dybo $1961: 37$ ). The non-final stress in Russ. éla must have arisen as a result of analogical development at a stage before Meillet's law (cf. Kortlandt $1975: 11$ ). Thus, I withdraw the argumentation put forward earlier in connection with these forms (1975:23).

In the following I shall give a chronological account of the history of Baltic accentuation after the example of Ebeling's well-known article on Slavic accentuation (1967). In particular, I intend to show how the accentual systems of the contemporary East Baltic languages are linked to their Proto-Indo-European origins by an uninterrupted chronological line. For the Prussian development I refer to my article on the subject (1974).

\section{Balto-Slavic}

Unlike Ebeling, I subscribe to Stang"s view that the stress patterns of the mobile noun declension in Slavic and Lithuanian agree to the extent that "a common Balto-Slavonic basis must be assumed " (1957 : 174). The problem of Balto-Slavic unity has often been misinterpreted. Since every known language shows dialectal variation, one must not conceive of Balto-Slavic as an absolutely homogeneous language, but rather as "a dialectal area which is so homogeneous that it is capable of carrying through common linguistic changes" (Stang $1957: 174$ ). The argument for the historical reality of the Balto-Slavic period is not the mere presence of a certain number of identical innovations, but the common chronology of these innovations. If such a chronology can be established, the intermediate stages can reasonably be called Balto-Slavic.

2.1. LOSS OF PIE ACCENTUAL MOBILITY. Proto-Indo-European stress

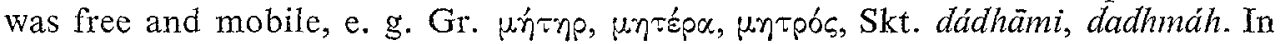
Balto-Slavic, I find no trace of PIE accentual mobility outside the nominal flexion of the consonant stems. When the old mobility was lost, an opposition between various paradigms with columnal stress arose, as in Sanskrit. The final accentuation 
of Lith. duktẽ originated at this stage. Athematic verb forms are end-stressed in Slavic, cf. Cakavian (Novi) dá, dämò. This is in agreement with the final accentuation of Lith. duodãs.

2.2. PEDERSEN'S LAW. The ictus was retracted from stressed inner sylla-

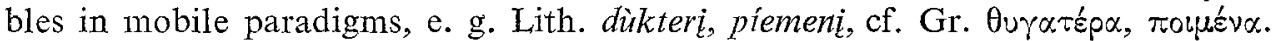
This retraction was first suggested by de Saussure, who added in a footnote: "Il est malheureusement difficile de dire le caractère exact qu'aurait cette loi, car il y a des obstacles à la transformer en loi phonétique pure et simple" (1922: 533). The solution was found by Pedersen, who proposed a "recul d'un accent qui contrastait avec un autre accent (final) dans le même paradigme, et qui à cause de ce contraste était exagéré et anticipé " $(1933: 25)$. Since this law was posterior to the loss of PIE accentual mobility, its application was limited to the flexion of polysyllabic consonant stems.

2.3. BARYTONESIS. The retraction of the ictus was analogically extended to vocalic stems in the case forms where Pedersen's law applied (de Saussure 1922: : 534, Pedersen 1933 : 26), e. g. Lith. ãvi, súm retracted in the pronouns anàs, katràs, and in the nom. pl. form of the $o$-stems, which had a very distinct phonemic shape, cf. dievaĩ.

2.4. OXYTONESIS. The ictus shifted from an inner syllable to the end of the word in paradigms with end-stressed forms (Ebeling $1967: 580$ ), e. g. Lith. sünumi, žiemomis. Though Ebeling formulated this law for Slavic only, the Lithuanian evidence suggests that it operated in Baltic as well. It is clear that Pedersen's law must have preceded the oxytonesis in mobile paradigms.

2.5. HIRT'S LAW. There are few laws in comparative linguistics which have been reformulated so many times by different scholars as the retraction of the stress to a preceding long vowel which was first established by Hirt (1895:94). The correct statement of the law seems to have been reached by Illič-Svityč $(1963: 80 \mathrm{f}$.): the ictus was retracted if the vowel of the preceding syllable was immediately followed by a laryngeal, e. g. Lith. dúona, výras, dúmai, móté, cf. Skt. dhānấh, vìráh, dhümáh,

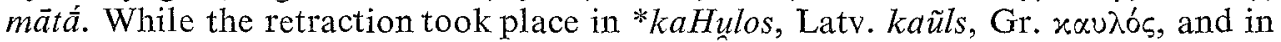
*gruHźlaH, Russ. grýzla, final stress was preserved in *tenHuos, Latv. tiêvs, Gr.

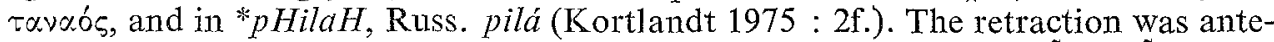
rior to the loss or the syllabic resonants because it affected Latv. ilgs, pilns, SCr. düg, pün. It was anterior to the elimination of zero grade before oblique case endings in the formative suffix of consonant stems because of the fixed stress reflected in Latv. mãte, $\mathrm{SCr}$, mäti. It was anterior to the merger of the glottalic feature with the reflex of the PIE laryngeals because the stress was not retracted in Latv. pệds, nuôgs. On the other hand, it was posterior to the oxytonesis, as Ebeling has convincingly demonstrated (1967: 582): the preservation of accentual mobility in words like $\mathrm{SCr}$. sin presupposes that the trisyllabic case forms of the $u$-stems had received final stress before Hirt's law operated.

As a result of Hirt's law, the ictus was retracted to the prefinal syllable in the polysyllabic case endings of the mobile $a H$-stems. The original distribution is still extant in Slovene, where the short vòwel in dat. pl. goràm and loc. pl. goràh points to original stress on the medial syllable, while the long vowel in the other flexion types must have received the ictus at a later stage, e. g. možệm, možéh. The same dis- 
tribution is suggested by the Old Prussian material (Kortlandt 1974 : 301). In Lithuanian, we find the expected medial stress in galvoms, but not in galvomis, galvosè, where the final accentuation must have been restored on the basis of the other flexion types. Conversely, the dat. pl. form of the other mobile flexion types adopted the accentuation of galvóms, and the resulting opposition between dative and instrumental stress spread to the dual forms. The new distribution is also found in Latvian, cf. dat. pl. siẽvãm, loc. pl. siẽvâs.

2.6. EBELING'S LAW. The ictus was retracted in a number of other cases, e. g. Lith. gen. sg. villko, dat. sg. vilkui, gálvai, 3rd sg. nẽša, nẽse, SCr. vûka, vâku, glâvi, pillo, aor. nèse. The assumption of a general accentual retraction in these forms was first put forward by Ebeling, who separated the Baltic and Slavic developments and explained the latter in terms of a homonymy condition (1967:584). In my critique of Ebeling's article I rejected the conditions and the chronology of the retraction and suggested a common Balto-Slavic development because of the close correspondence between Lithuanian and Slavic $(1975: 5 \mathrm{f}$.): in disyllabic word forms the stress was retracted from a final short or circumflexed vowel or diphthong unless the preceding syllable was closed by an obstruent. Assuming that the laryngeals were still ordinary consonants at this stage, we can simply say that the stress was retracted from final open syllables. Final accentuation was preserved in nom. sg. ${ }^{*}$ golHuaH, gen. sg. *oveiS, gen. pl. *uilkoN, Lith. galvà, aviẽs, vilkü, and in *pHilaH, *neślo, *neśtei, Russ. pilá, nesló, nestí. Word-final *t/d had already been lost at this stage (cf. Kortlandt $1975: 45$ ). If the final accentuation reflected in SCr. 3rd pl. aor. kléše is old, the syllabic resonants had already been dissolved. The final stress may have been restored, however, because sigmatic aorist forms are generally end-stressed in Slavic.

As I pointed out in my discussion of Slavic accentuation, the retraction of the ictus referred to as Ebeling's law was posterior to the one known as Hirt's law (1975: : 6). The accentual mobility in Russ. dalá, dálo, which is also reflected in other Slavic languages and which mist have arisen as a result of Ebeling's law, presupposes an end-stressed paradigm at an earlier stage. If the root of this word contained full grade vocalism, Hirt's law would have retracted the ictus and prevented the rise of accentual mobility. Consequently, we have to assume that an original zero grade was replaced with a full grade at a stage which was posterior to Hirt's law but anterior to Ebeling's law. If the argument put forward above in connection with $\mathrm{SCr}$. klése is correct, the loss of the syllabic resonants must also be dated between these two accentual developments.

2.7. WINTER'S LAW. The PIE glottalic consonants dissolved into a laryngeal and a buccal part. The former merged with the reflex of the PIE laryngeals and the latter with the reflex of the voiced aspirates. As pointed out above, Winter's law was posterior to Hirt's law because the broken intonation in Latv. pêds, nuôgs reflects earlier accentual mobility. It was also posterior to the loss of final $* t / d$ because of the Slavic neuter pronoun to. I find no evidence for the relative chronology of Winter's law in relation to Ebeling's law or to the loss of the syllabic resonants.

Winter's discovery brings the Balto-Slavic archetype once again closer to the state actually observed in Sanskrit. We can now completely identify OChSl. azz with Skt. ahám as PIE *ếHom. Even more striking is the solution which presents 
itself for the athematic verb flexion. OChSl. jamb, věmb, jadęt $\zeta$, lědęt $r$ regularly continue *edmi, *uoidmi, *ednti, *uoidnti. The consonantal opposition between Skt. dádhämi and dádami is reflected in contemporary Lithuanian by the quantitative and intonational difference between dedì and duodu. The reduplication syllable had apparently adopted the timbre of the root vowel. The correspondence between OChSl. dadet r and Skt, dádati is perfect: both forms point to *dodHnti. The hypothesis that $\mathrm{OChSl}$. damo continues *dodHmi rather than *doHmi is supported by the final accentuation of the paradigm in Slavic; cf. also Latv. duômu and OLith. demi. The alleged form dëmi, which would support the latter reconstruction, „,nèra kalbos faktas, bet gramatikų pramonè (Būga 1922 : 158).

\section{East Baltic}

While the relative chronology of accentual innovations strongly supports the hypoihesis that there was a period of common Balto-Slavic development after the disintegration of the Indo-European proto-language, I see no evidence for a similar period of shared innovations in the Baltic linguistic area after its separation from Slavic. Though Prussian is undoubtedly closer to the East Baltic languages than to Slavic, the characteristic features of the Baltic languages seem to be either retentions or results of parallel development and cultural interaction. Thus, $I$ assume that Balto-Slavic split into three identif iable branches, each of which followed its own course of development.

Numerous shared innovations in the East Baltic languages date from a period of common evolution. The establishment of their relative chronology poses several problems which fall outside the subject of this paper. Here I shall confine myself to a general statement of the main developments.

3.1. Among the earliest East Baltic innovations the homogenization of diphthongs is of particular importance. Stressed * $e i,\left.* a i\right|^{*} o i$ were monophthongized into ${ }^{*} \bar{e}$. The resulting vowel was diphthongized into ie at a later stage, e. g. Lith. dievas, Latv. dievs. The development was first established by Hirt (1892:37) and evoked a lot of discussion in later years. Endzel in maintained that the monophthongization was limited to *ei (1907), but this cannot be correct, e. g. Lith. dieveris,

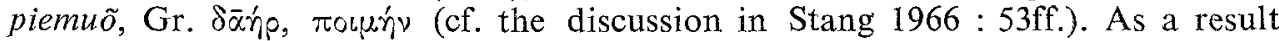
of this development, the vowel system changed from triangular to quadrilateral and thereby entailed a shift in the ablaut relations. When the parallelism between ${ }^{*} \bar{e}$ and $* \bar{o}$ was broken, the new lengthened grade $* \vec{a}$ became very productive in East Baltic. On the other hand, the apophonic relationship between $* i$ and ${ }^{*} \bar{e}$ gave rise to a similar alternation between $* u$ and ${ }^{*} \bar{o}$ (cf. recently Karaliūnas 1973 ). In unstressed syllables $* \bar{a}$ and $* \bar{o}$ merged, e. g. Lith. dovana and the gen. sg. ending $-o$. The analogical introduction of new ${ }^{*} \bar{e},{ }^{*} \bar{o}$ in unstressed syllables evoked a large number of levellings.

At the same time phonemic length was lost in diphthongs, e. g. dat. sg. mergai. The double reflex of $* \bar{o} i$ shows that the shortening was carried out partly before and partly after the reshuffling of the apophonic relations. The divergent developments of the instr. pl. vilkais and the dat. sg. viĩkui suggest that the shortening of long diphthongs was early in closed final syllables and late in open final syllables. In some 
dialects the final $i$ of the dat. sg. ending was lost, as it was in Slavic, e. g. Gervèčiai vilkkuo.

3.2. The development of nasal vowels from *en, *an, e. g. Lith. kêsti, kąsti, and the rise of phonemic pitch can also be dated to the East Baltic period. Phonemic pitch originated when the laryngeals lost their segmental status and became a feature of the neighbouring vowel. It is difficult to see exactly at what stage the transformation of the laryngeals into a vocalic feature occurred. I think that it must be connected with the simplification of diphthongs. In Slavic, the loss of the laryngeal as a segmental phoneme is part of the general elimination of closed syllables. In Baltic, the simplification of diphthongs was limited to the innovations mentioned above. I see no sufficient evidence for a chronological differentiation between the rise of phonemic pitch and these developments. Thus, I assume that $* H$ changed into ${ }^{*} \hat{e}$ in the same period when ${ }^{*} e i$ developed into $* \bar{e}$ and $* e n$ into $*$. These transitions have in common that a segmental phoneme changed into a vocalic feature. While the first phase of Winter's law, the dissolution of the PIE glottalic consonants, was undoubtedly Balto-Slavic, I am inclined to date its second phase, the fusion of the glottalic articulation with the features of the preceding vowel, to the separate branches of the Balto-Slavic subfamily.

The rise of phonemic pitch does not imply the rise of a tonal opposition. I propose to use the term "pitch" for any vowel feature which is neither timbre nor quantity, and to reserve the term "tone" for rising" and falling tone movements. Though the rise of phonemic pitch dates from the East Baltic period, I assume that its development into tone took place independently in Latvian and Lithuanian. The original laryngeal pitch must have been similar to the Latvian broken intonation, the Danish stød, or the pitch in Vietnamese $m a{ }^{\prime}$ 'rice seedling'. Indeed, this intonation has been preserved under the stress in Žemaitian and outside the stressed syllable in Latvian. I think that the contemporary Žemaitian facts throw an interesting light upon the origin of tonal oppositions and metatony in the two East Baltic languages, as will be indicated below.

3.3. Perhaps the last common East Baltic development was the retraction of the ictus from a prevocalic $i$, e. g. Lith. kur̃pius (kùrpè), ragãnius (rägana), aükštis (áukštas), bẽgis (bëgti), vandẽnis (vanduõ), cf. Skt. udaníyah, Gr. rouólos. The metatony is discussed below. Other examples: auksinis (áuksinas), vyriškis (výriškas),

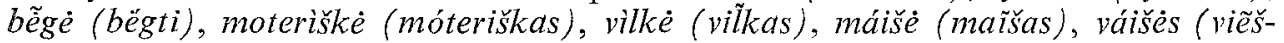
pats), žmónès (žmogùs), asõtis (ąsótas), beržỹye (beržýnas).

Baltic $\bar{e}$-stems have three different origins. Some words go back to $e H$-stems, e. g. Lith. mentẽ , šãkès, cf. Skt. mánthāh, šăkhāa, probably also Lith. žvaigždé. These words have obtained other suffixes in Slavic, e. g. Polish matew, gwiazda, (dial.) pqć, cf. Skt. pánthäh. Other words go back to ieH-stems, e. g. Latv. snãte, Lith. mẽde, cf. mẽdžias, Skt. mádhyam, possibly also Lith. žẽmé. These words have merged with the next group in Slavic, cf. Russ. mežá, zemljá. A third group of words go back to $i a H$-stems, e. g. Lith. didele, vilke. I assume that in Balto-Slavic the syllabic character of a prevocalic $i$ was preserved if either the $i$ or the following vowel was stressed, cf. Lith. gaidỹs from *gaidiás, but gen. sg. gaĩdžio, dat. sg. gaídžiui, and Estonian takijas from Lith. dagỹy, Latv. dadzis. This hypothesis is corroborated by the difference between OChSl. bogynji, Lith. pati, gen. sg. pačios (with secondary 
circumflex), and OChSI. sodbji, Lith. vilke (cf. Lohmann 1932 : 63f.). The former type goes back to the proterodynamic and the latter to the hysterodynamic flexion, cf. Skt. deví, gen. sg. devyáh from *déviH, *devyáHs versus vrkth́h, gen. sg. vrkíah from * $v_{r} k i H s,{ }^{*} v r k i H a ́ s$. The fact that OChSl. sodbji was stressed on the medial syllable before Dybo's law operated follows unmistakably from the combination of short root vowel in Polish sedzia and final accentuation in Russ. sud'já (cf. Kortlandt $1975: 30$ ). Thus, I assume that Lith. vilke developed regularly from *uilki$\mathrm{HaH}$ when the stress was retracted in connection with the elimination of prevocalic $i$. The latter development was preceded, and possibly evoked, by the loss of the laryngeal as a segmental phoneme. The parallel with Sanskrit, where the nom. pl. vrkiah developed into vrkyah after the loss of the laryngeal, is striking. The retraction of the ictus from a prevocalic $i$ caused the rise of several systems of tonal oppositions in the East Baltic languages (cf. Stang 1966 : 144ff.).

\section{Lithuanian}

The following relative chronology is derived mainly from the Aukštaitian material, on which the literary language is based. The Zemaitian dialects did not take part in some of the early evolutional links but shared some of the later developments, which points to the maintenance of a deep-rooted dialectal differentiation for a long period of time. While certain isoglosses between Aukštaitian and Žemaitian are as least as old as those between Lithuanian and Latvian, the latter language followed a distinctly different course at a more recent stage.

Not all innovations can be dated with the same degree of precision. Apart from the fact that in different areas certain developments took place at different stages, the independent character of some innovations does not allow one to establish their relative chronology. Thus, I find very little evidence for dating Nieminen's law (1922 : 151ff., cf. Stang $1966: 171$ ), according to which the ictus was retracted from a short $a$ in final syllables. This retraction may have taken place at any stage before Leskien's law.

4.1. RISE OF TONAL OPPOSITIONS. Retraction of the ictus onto a laryngealized vowel yielded rising tone and loss of the laryngeal feature, e. g. aũkštis (2), cf. áukštas (3). The old pitch opposition was maintained when the ictus was not retracted. In stressed syllables, the laryngeal pitch feature then changed into a falling tone and the non-laryngeal pitch merged with the new rising tone. Retraction of the ictus onto a non-laryngealized long vowel or diphthong yielded a middle tone, which later merged with the new falling tone, e. g. vilke (1), cf. Skt. vrkîh. The whole development is analogous to what we find at a much later date in Zemaitian dialects (cf. Aleksandravičius 1957). In Kretinga, the stress is regularly retracted to the first syllable of the word except from laryngealized vowels as in galvûoms (galvóms), siedîete (sédëti). Retraction onto a laryngealized vowel yields rising tone and loss

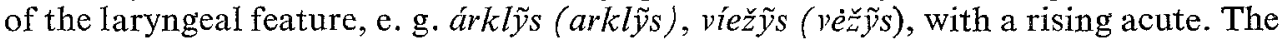
old pitch opposition is maintained in ômž̆os (ámžius), mãišos (maĩ̌as). The circumflex is falling in this dialect, as in Latvian. Retraction of the stress onto a non-laryn-

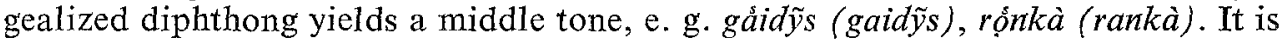


clear from the latter example that both de Saussure's law and Leskien's law preceded the Žemaitian retraction of the ictus. The distinction between the new rising tone and the middle tone was lost in Kretinga (Zinkevičius 1966 : 40fn.), but has been preserved in neighbouring dialects, e. g. in Kalnalis.

4.2. DIPHTHONGIZATION OF $\bar{e}, \bar{o}$. East Baltic * $\bar{e},{ }^{*} \bar{o}$ were diphthongized into ie, uo, e. g. diẽvas, dúoti. This development was limited to the Aukštaitian dialects. Both the internal and the comparative evidence point to a relatively early date of the diphthongization in stressed syllables. On the one hand, it probably preceded the lengthening of stressed $e, a$, as is indicated below. On the other, it affected all and only the Aukštaitian dialects (cf. Zinkevičius 1966:503). In unstressed syllables the diphthongization may have been more recent, as it probably was in Latvian.

4.3. LENGTHENING OF STRESSED $e$, a. Baltic * $e$, * $a$ were lengthened under the stress in non-final syllables, e. g. vẽda, sãko. This development was also limited to the Aukštaitian dialects. The new long vowels did not coalesce with Baltic ${ }^{*} \bar{e},{ }^{*} \bar{a}$, which had become $\dot{e}, o$ at this stage. The diphthongization of East Baltic $* \bar{e}, * \bar{o}$ probably preceded the neutralization of length in stressed syllables, because otherwise we have to assume four degrees of aperture in the long vowel system at a time when there were two degrees of aperture in the short vowel system. Such a reconstruction is hardly compatible with the elaborate system of tonal oppositions which is characteristic of the Baltic linguistic area. It is probable that the lengthening of $e, a$ was originally limited to open syllables and that the long vowel in acc. sg. nãkti and in such words as äpdaras is analogical. This assumption explains the absence of lengthening in the comparative, e. g. gerèsnis, and in the future and conditional, e. g. dègsiu, dègćiau. It also accounts for the fact that the lengthening did not affect final syllables. The long vowel was later extended analogically in the Southern and Central dialects.

4.4. PEDERSEN'S LAW again. The ictus was retracted from stressed inner syllables in mobile paradigms, e. g. nèveda, priveda, nèvedé. This retraction re-introduced short $e, a$ under the stress in open syllables. The ictus was not retracted in nesãko, nesãke because the latter paradigm had fixed stress until de Saussure's law operated. The retraction in nèveda cannot be identical with the retraction in the acc. sg. vãkarq, vãlanda because of the different quantity of the stressed vowel: the latter retraction must have preceded the lengthening of stressed $e, a$, whereas the former must have been later. Indeed, I assume that the lateral mobility in vãkaras, valandà originated from the Balto-Slavic barytonesis, as was indicated above. The accentual mobility in vedì, vẽda was a result of Ebeling's law. The hypothesis that this verb was originally end-stressed and that its mobility arose from a retraction of the stress, not from a progressive accent shift, is based on the final stress of the participle ved a s and corroborated by the Slavic evidence. Thus, we may compare the stress patterns of sãko and veda with the nominal accent classes (2) and (4), respectively. In Slavic, as in Lithuanian, we have to assume that Pedersen's law operated once again after the dissolution of the Balto-Slavic unity and then yielded the accentuation of Russ. $n a ́$ vodu, né byl, pródal. Since the retraction of the stress to a preposition from barytone forms of mobile paradigms is unknown in Baltic, it cannot be dated to the Balto-Slavic period, where the lateral mobility in the noun inflection arose. Further evi- 
dence for the dating of the Slavic retraction is provided by the accentuation of nominal prefix formations (cf. Kortlandt 1975:28).

4.5. HJELMSLEV'S LAW. Retraction of the ictus onto a laryngealized vowel yielded rising tone and loss of the laryngeal feature, e. g. édesis, ẽdalas, ẽsena, taũkinas, añtinas. This law is of course simultaneous with Pedersen's law. According to Hjelmslev's original formulation, "toute syllabe accentuée revêt $l$ 'intonation de la syllabe immédiatement suivante“ (1932 : 5). I agree with Pedersen that, ,M. Hjelmslev a attribué à la loi de métatonie qu'il a si heureusement trouvée, une portée trop grande" (1933 : 10). Indeed, I think that the same objection can be made to Pedersen's reformulation of the law, according to which its application was limited to words of more than two syllables. Most of the instances which, in my opinion, Pedersen attributes incorrectly to Hjelmslev's law, received their metatonical intonation as a result of the retraction of the stress from a prevocalic $i$. Here I have reformulated the law in such a way that it accounts for precisely those cases of métatonie douce which Stang calls ,nicht verständlich" and ,schwer zu verstehen" (1966: : 154). In the theory put forward here, the apparent tonal assimilation is the result of a retraction of the ictus, which is what all varieties of phonetic metatony have in common. The original non-initial accentuation of words like añtinas is supported by the final stress in the paradigm of Russ. ovén, SCr. óvan.

4. 6. DE SAUSSURE'S LAW. The ictus shifted from a non-falling vowel to a following laryngealized vowel, e. g. nom. sg. and instr. sg. rankà, acc. pl. rankàs, 1st sg. galiù, sakaũ. Pedersen's law preceded de Saussure's law because the stress is not retracted in negãli, nesãko: these paradigms hadfixed stress until de Saussure's law operated. As the great master of Indo-European linguistics pointed out himself $(1922: 530)$, the progressive accent shift eliminated the retraction of the stress to a prefix in the paradigm of verbs with an acute root vowel. This in turn led to the almost complete disappearance of the verbal stress pattern which corresponded to nominal accent class (3). The previous existence of such a type is still testified

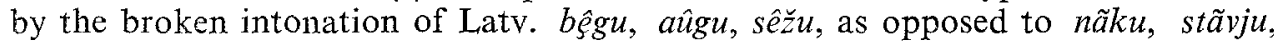
cf. Russ. 3rd pl. begút, sidját versus stávjat. Its only remnants in Lithuanian are the end-stressed participial forms duodzqs and $\dot{e} d \tilde{a} s$, cf. Latv. duômu, êmu.

There is no indication that de Saussure's law ever operated in Latvian. ,Im Lettischen ist die Frage prinzipiell unlösbar", according to Stang (1966:172). However, the same author assumes that de Saussure's law did operate in Latvian in order to account for the alternation between $e i$ and $i e$ in the athematic paradigm of the verb iet (1966:58f.), e. g. Varaklāni èimu, è $i \hat{t} t$. In fact, the accentual mobility in this word is definitely older than de Saussure's law and should be compared with Lith. vedù, vêda, not with galiù, gãli: it continues an original end-stressed paradigm which became mobile as a result of Ebeling's law. There are two weighty arguments in favour of the view that de Saussure's law was limited to Lithuanian. Firstly, the law was preceded by Pedersen's law, which was in turn preceded by the exclusively Lithuanian lengthening of stressed $e, a$. The law must therefore have operated either independently or not at all in Latvian. Secondly, the operation of the law was certainly favoured by the rising tone of the Lithuanian circumflex. This argument was already put forward by de Saussure (1922 : 526fn.). In Latvian, the falling circumflex rather favoured a retraction of the stress. Thus, $I$ think that 
the stabilization of the ictus on the initial syllable of the word was the Latvian counterpart of de Saussure's law in Lithuanian.

It is remarkable that de Saussure's law did not operate in the paradigm of the future tense, e. g. tàpsiu, pirrksiu. This accentuation cannot be analogical because there was no model for it. Consequently, we have to conclude that these forms were trisyllabic at the stage when the progressive accent shift operated. The anomaly can be explained if we assume a variant of Sievers' law for Lithuanian: posttonic prevocalic $i$ retained its syllabic character if it was preceded by more than one obstruent. Since the identity of the suffix with Skt. -sya-is hardly open to doubt, the different accentuation is remarkable. The absence of end-stressed future forms in the archaic dialects of Lithuanian is just as striking as the absence of root-stressed sigmatic aorist forms of verbs with consonantal stems in Slavic. Latvian testifies to the antiquity of the root-stressed future in Baltic, e. g. Varaklāni $\hat{\imath} S \mathcal{S} u$, with $i$ reflecting ie. The infinitive adopted the accentuation of the future in those cases where the ictus had not yet been retracted as a result of Hirt's law.

4.7. LESKIEN'S LAW. Acute vowels in final syllables were shortened, e. g. rankà, rankàs. This development was established by Leskien (1881). It is obvious that it cannot have preceded de Saussure's law or Nieminen's law. After Leskien's law, the tonal opposition on final diphthongs was lost outside Žemaitian, e. g. sa$k a \tilde{u}, t i \tilde{e}$. It was restored by the loss of posttonic short vowels in final syllables, e. g. vaikáms, tảm.

\section{Latvian}

The fixation of the stress on the initial syllable and the analogical levelling of the tone in paradigms makes it impossible to establish the relative chronology of accentual developments in Latvian with the same degree of precision as has been done for Lithuanian. I shall therefore be brief in this section.

5.1. Retraction of the ictus yielded rising tone on both laryngealized and plain vowels, e.g. sniẽdze. The other stressed vowels became falling per oppositio n em. e. g. sniegs, cf. Lith. sniẽgas. The loss of the laryngeal feature under the falling tone yielded a stretched intonation, which later merged with the new rising tone, e. g. sẽt, cf. Lith. sëti. Finally, the remaining laryngealized stressed vowels, which had lost their distinctive tone when the laryngeal feature was lost under the falling tone, became falling, as in Lithuanian, e. g. sèja. I think that this interpretation of the facts explains why the laryngeal feature was apparently lost earlier in stressed than in unstressed syllables.

5.2. Baltic *in, *en, *an, *un developed into nasal vowels. Later the nasal element was lost and they merged with $*_{i},{ }^{*} \bar{e}, * \bar{o}, * \bar{u}$. Finally, East Baltic ${ }^{*} \bar{e},{ }^{*} \bar{o}$ were diphthongized into ie, uo, e. g. dievs, gùovs. The diphthongization was probably posterior to the elimination of the nasal vowels because the latter shared this development, e. g. pieci, luôgs, cf. Lith. penkì, lángas.

5.3. The stress became fixed on the initial syllable of the word. As I suggested above, this development is complementary to de Saussure's law in Lithuanian. Af- 
ter the stabilization of the ictus, long vowels and diphthongs in final syllables of polysyllabic words were shortened while most short vowels were syncopated. This in turn led to the disintegration of the tonal system in the contemporary dialects.

\section{References}

Aleksandravičius J. 1957. Kirtis ir priegaidè Kretingos tarmeje. - LKK, t. 1, p. $97-107$.

Būga K. 1922. Kalba ir senovè. K.

Д ыбо В.А. 1961. Ударение славянского глагола и формы старославянского аориста. - „Краткие сообщения ин-та славяноведения“, т. 30, с. 33-38.

Ebeling C. L. 1967. Historical laws of Slavic accentuation. - In: To Honor Roman Jakobson. (Essays on the occasion of his seventieth birthday.) The Hague, p. $577-593$.

Эн дзелин Я. 1907. О происхождении литовско-латышского ie. - „Известия отделения русского языка и словесности“", т. $12 / 1$, с. 40-66.

Gamkrelidze T., Ivanov V. 1973. Sprachtypologie und die Rekonstruktion der gemeinindogermanischen Verschlüsse. - „Phonetica“, t. 27, p. 150-156.

Hirt H. 1892. Vom schleifenden und gestossenen Ton in den indogermanischen Sprachen. - IF, Bd. 1, p. 1-42 und p. 195-231.

1895. Der indogermanische Akzent: Ein Handbuch. Strassburg.

Hjelmslev L. 1932. Études baltiques. Copenhague.

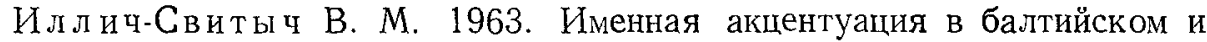
славянском. Судьба акцентуационных парадигм. $M$.

Karaliūnas S. 1973. Iš lietuvių kalbos io-kamienụ veiksmažodžių istorijos (uo šaknies vokal zmo tipas). - LKK, t. 14, p. 7-150.

Kortlandt F. H. H. 1974. Old Prussian Accentuation. - KZ, Bd. 88, p. $299-\Sigma 36$.

1975. Slav.c Accentuation. (A study in relative chronology.) Lisse.

Leskien A. 1881. Die Quantitätsverhältnisse im Auslaut des Litauischen. AfslPh, Bd. 5, p. 188-190.

Lohmann J. 1932. Genus und Sexus. Göttingen.

Nieminem E. 1922. Der urindogermanische Ausgang -ai des NominativAkkusativ Pluralis des Neutrums im Baltischen. Helsinki.

Pedersen H. 1933. Études lituaniennes. Copenhague.

De Saussure F. 1922. Recueil des publications scientifiques. Genève.

Stang C. S. 1957. Slavonic Accentuation. Oslo.

1966. Vergleichende Grammatik der baltischen Sprachen. Oslo.

Watkins C. 1965. Evidence in Balto-Slavic. - In: Evidence for Laryngeals. The Hague, p. 116-122.

Winter W. 1976. The distribution of short and long vowels in stems of the type Lith. ésti : vèst $i$ : mèst $i$ and OCS jast $i$ : vest $i$ : mest $i$ in Baltic and Slavic languages, to be published in: Recent Developments in Historical Phonology. The Hague.

Zinkevičius Z. 1966. Lietuviụ dialektologija (Lyginamoji tarmiụ fonetika ir morfologija.) V. 
В статье обсуждается относительная хронология развития балтийской акцентуационной системы от индоевропейского праязыка до современных восточнобалтийских языков. Автор возводнт балто-славянскую акутовую интонацию к индоевропейским ларннгальным и глоттализованным (в классической теории, звонқим непридыхательным) согласным, а циркумфлексовую - $\mathrm{k}$ ранним стяжениям и удлинениям. Хронология акцентуационных явлений приводит нас к принятию гипотезы о перноде общего балто-славянского развития. По мнеиию автора, происхождением фонетической метатонии в восточпобалтийских языках является оттягивание ударения в определенных условиях. Закон де Соссюра относится к позднему периоду развития литовского языка. Установление пеподвижного удареиия на начальном слоге в патышском языке рассматривается как развитне, соответствугщее закону де Соссюра в .титовском.

\section{SMULKMENOS}

\section{XXXIV}

Daiktavardžių šuo ir žmogus daugiskaitos vardininkas palyginti didelèje lietuvių kalbos tarmių dalyje turi priebalsinio linksniavimo formas šùnes 'šunys', žmónes '̌̌monės'. Pirmąją vartoja (pagal naująji tarmių skirstymą) vakarų aukštaičiai kaunǐškiai bei artimesni žemaičiai (pvz., apie Er̃žvilką, Raséinius), pietų aukštaičiai, rytų aukštaičiai vilniškiai, uteniškiai, dalis anykštẻnų bei kupiškënų (maždaug iki linijos Aluntà - Kùpiškis - Papilỹs). Antroji (žmónes) vartojama kiek siauriau: pastebèta kai kuriose vakarų aukštaičių (pvz., Garliavà), pietų aukštaičių (pvz., Rudaminà, Kaniavà), rytų aukštaičių vilniškių (Liñkmenys, KaĨtanėnai, Tverẽčius, Adùtiškis...) ir uteniškių (Sãlakas...) šnektose. Plačiau vartojama $i$ kamieno forma žmónys. Ją turi daugelis žemaičiu (Kretingà, Mažeîkiai, Luõke, Pãgramantis...), kai kurios vakarų aukštaičių (Jùrbarkas, Šiauliaĩ, Šakýna...), rytų aukštaičiu panevėžǐškiu (pvz., Bìržai) ir pietų aukštaičiu (Veisiejaĩ, Kabẽliai, Palómené...) šnektos. J. Sliavas linkęs manyti, kad formas sùnes, žmónes buvo išlaike ir šiauriniai panevèžiškiai, tik čia jụ dabar neįmanoma atskirti nuo šùnys, žmónys, nes dél stiprios galūnių redukcijos -es ir -ys susiliejo $i$ vieną -'s (apostrofas rodo neaiškios kokybès murmamąji garsa). Dar palyginti neseniai šios galūnès turèjo būti skiriamos ${ }^{1}$. Liaudies dainose, kur paprastai galūnès neredukuojamos, ir dabar esą dainuojama: visi šunes loja... visi žmones šneka.

J. Šliavas savo $1948-1949 \mathrm{~m}$. mokykliniuose sąsiuviniuose radęs daugybe kartų parašyta šunes, žmones vietoj šunys, žmonés. Jis prisimena, kad nepaisant mokytojo taisymų, jam buvę sunku ịprasti rašyti šunys, žmonés. Ar tẻvai ir kiti senesnieji Rimkúnų kaimo (Linkuvôs apyl.) gyventojai tada dar ištardavę sveiką galūnę -es, jis neatsimenąs.

Šios tarmès galūnè -es negali būti kilusi iš -ès (žmónes iš žmónẻs), nes čia pastaroji ištariama -ess, pvz., žẽmess 'žemès'.

Z. Zinkevičius

1 A. Baranausko surinktuose praeitame šimtmetyje šios tarmès tekstuose (A. Ba ra n ow s ki. Litauische Mundarten. Bd. I. Leipzig, 1920) trumpieji galūnès balsiai (ir $i$ iš $i$, $i$ ) dar kartais pažymimi, pvz., nom. sg. kǐšls $140_{28}$ 'kiškis', bet sañãls $143_{13}$ 'senelis', nom. pl. bĩt's $147_{14}<$ bitys 'bitès', bet acc. pl. šòniśs $147_{19}<$ šunis. 